KAWISTARA

VOLUME $4 \quad$ No. 3, 22 Desember 2014

Halaman 225-330

\title{
MOBILITAS KELAS BARU DI DUNIA INDUSTRI PARIWISATA
}

\author{
Bambang Suharto \\ Fakultas Sastra dan Budaya Universitas Negeri Gorontalo \\ Email: unikbali@hotmail.com \\ Janianton Damanik \\ Fakultas Ilmu Sosial dan Ilmu Politik \\ Universitas Gadjah Mada \\ M.Baiquni \\ Fakultas Geografi \\ Universitas Gadjah Mada \\ Chafid Fandeli \\ Sekolah Tinggi Teknik Lingkungan Yogyakarta
}

\begin{abstract}
The main study of this research solves the researchers empirically debate about the source of in justice in the world tourism industry because of the class structure. First, the theory of post industrial related class should look more human. The second, related theory of Marx saw class more regularly and degraded. This study used a mixed methods concurrent triangulation. Results of the analysis relationship between classes show that there was a new class strengthened, namely the professional classes $(54.5 \%)$ that have a high bargaining power against capital classes $(1.5 \%)$ and the proletariats $(44 \%)$. These conditions reinforce the post industrial theory which shows that the system is open, technological advances, and specifications facilitate mastery of the field of expertise towards a higher level of professionalism based proclean care era cross borders and not consistent proletarianization process. This studies timated the transformation of the proletariat in to a new class structures end to be stronger, in line with the direction of the professional class distributed double post status other than capitalist-professional worker as well small to large scale.
\end{abstract}

Keywords: Class, Mobility, Tourisms Industry.

\begin{abstract}
ABSTRAK
Kajian utama dari penelitian ini adalah mengatasi secara empiris perdebatan para peneliti mengenai sumber ketidakadilan di dunia industri pariwisata karena adanya struktur kelas. Pertama, terkait teori pascaindustri yang melihat kelas harus lebih manusiawi. Kedua, terkait teori Marx yang melihat kelas lebih teratur dan terdegradasi. Penelitian ini menggunakan metode campuran triangulasi konkuren. Hasil analisis dari hubungan antarkelas menunjukkan bahwa ada kelas baru yang menguat, yaitu kelas profesional $(54,5 \%)$ yang mempunyai posisi tawar tinggi terhadap kelas kapital $(1,5 \%)$ dan kelas proletariat $(44 \%)$. Kondisi ini semakin menguatkan teori pascaindustri yang menunjukkan bahwa sistem yang terbuka, kemajuan teknologi, dan spesifikasi bidang memudahkan penguasaan keahlian menuju
\end{abstract}


tingkat keprofesionalan yang semakin tinggi berbasiskan proclean career lintas batas dan bukan proses proletarisasi konsisten.Dari penelitian ini diperkirakan transformasi kelas proletariat ke struktur kelas baru cenderung semakin menguat, seiring dengan terdistribusikannya kelas profesional ke arah status rangkap jabatan selain pekerja sekaligus kapitalis-profesional skala kecil hingga besar.

Kata Kunci:Kelas, Mobilitas, Industri Pariwisata

\section{PENGANTAR}

Belakangan ini artikel bertema struktur kelas dalam pekerjaan (misalnya, Ehmer, 2014; Evans dan Colin, 1998)dan munculnya kembali pertentangan pendapat tentang hubungan antarkelas di industri pariwisata telah menarik banyak perhatian umum dan dikaji di berbagai artikel ilmiah (lihat, Marx, 2006; Goldthorpe, 2000; Magnis-Suseno, 1999; Guy dan Allen, 1975; Friedman, 1974). Namun demikian, penelitian tentang munculnya kelas-kelas baru hingga ke masalah kesejahteraannya belum banyak ditemukan.

Padahal, adanya kelas baru bisa jadi memotivasiusaha seseorang untuklebihaktif, bukan sebaliknya, asal dengan kesempatan yang sama orang bisa menduduki kelas apapun itu. Barangkali karena alasan itu pulalah semua orang berjuang berdarahdarah ingin naik kelas untuk meningkatkan kesejahteraannya agar tidak teralineasi. Hampir di setiap sektor, institusi pemerintah, lembaga-lembaga dunia membangun komitmen politik untuk menyejahterakan kelas yang diduga teralineasi tersebut, bahkan serangkaian kajian, diskusi, seminar, konferensi, dan lokakarya telah dilakukan, seperti konferensi tahunan ILO 2009 di Bali.

Memang tidak dapat dipungkiri sebagaimana dijelaskan sebelumnya bahwa topik kajian tentang struktur kelas di industri pariwisata telah banyak ditulis,seperti oleh Wright dan Martin (1987), Wright dan Singelmann (1982), Farmer (1966), dan Friedman (1974). Akan tetapi, kajian semacam itu lebih banyak bersifat mendikotomikan dua kelas yang antagonis, yaitu antara kelas proletariat dengan kelas kapitalis. Berbeda dari penelitian-penelitian sebelumnya, penelitian ini mengkaji kemungkinan-kemungkinan muculnya kelas baru, khususnya analisis antarkelas dengan konsep keharmonisan yang diperkenalkan dan kemudian dikembangkan oleh Anker (2002), sehingga mampu membangun kesejahteraan ke semua kelas. Yang dimaksud dengan kelas di sini adalah golongan atau kumpulan pekerja di berbagai jenis usaha di industri pariwisata berdasarkan persamaan sifatsifatnya (Rose dan Karen, 1997). Dalam kaitan itu, ancangan analisis kelas ini dipilih karena dapat mengungkapkan kategori-kategori kelas (Rose dan Karen, 1997) dan karena memiliki nilai penting untuk munculnya kelas-kelas baru (Korpi, 1983), serta secara empiris teruji (Anker, 2002).

Secara khusus, penelitian ini bertujuan untuk menganalisis struktur kelas yang terdapat pada struktur pekerjaan di berbagai jenisusaha di industri pariwisata KedongananJimbaran Bali. Akhirnya, diharapkan dari hasil penelitian ini dapat mendorong kelas yang teralineasi naik kelas dan masukan langsung kepada pemegang kebijakan untuk memberikan akses terhadap mereka.

Struktur kelas dipahami dalam suatu struktur pekerjaan di berbagai jenis usaha di industri pariwisata Kedongan-Jimbaran Bali. Caranya, penelitian triangulasi konkuren dilakukan sebagai berikut. Wawancara mendalam dilakukan terhadap 10 informan dengan teknik snowbowl danpengamatan lapangan dilakukan di tempat usaha pariwisata yang berbeda-beda yang dipilih secara purposive dalam waktu yang sama. Sementara itu, survai menggunakan kuesioner dilakukan terhadap sampel pekerja sebanyak 789 responden yang diambil secara random sampling dari populasi 8.641 pekerja di 528 industri pariwisata (lihat, Morgan, 2007; Ritchie dan Goeldner, 1994). Data kualitatif hasil wawancara dan pengamatan serta data kuantitatif frekuensi kelompok kelas yang didapatkan dari hasil olahan program software SPSS 19 dianalisis. Hasil analisis triangulasi yang berupa temuan induktif dan deduktif 
diintegrasikan keduanya dan disimpulkan menjadi satu kesatuan temuan yang utuh saling menguatkan (Creswell, 2012).

\section{PEMBAHASAN}

Berdasarkan pengamatan lapangan (2013) menunjukan bahwa berbagai jenis usaha di industri pariwisata sangat terkait erat dengan keruangan geotopografi, efek sirkulasi kapital, dan kondisi tenaga kerja yang tersedia.Sehubungan dengan hal itu, corak atraksi wisata yang dipasarkan dan variasi jenis usaha di industri pariwisata yang tumbuh produktif di lokasi penelitian Kedonganan-Jimbaran dapat dilihat pada tabel 1.

Tabel 1

Distribusi Responden Berdasarkan Jenis Usaha di Industri Pariwisata

\begin{tabular}{l|l|l|l}
\hline No & Jenis Usaha dalam Industri Pariwisata & N & Persentase \\
\hline 1 & Daerah tujuan wisata (dtw) & 4 & 0,5 \\
\hline 2 & Bisnis perjalanan wisata (bpw) & 5 & 0,6 \\
\hline 3 & Akomodasi & 210 & 26,6 \\
\hline 4 & Kuliner & 295 & 37,4 \\
\hline 5 & Souvenir & 216 & 27,4 \\
\hline 6 & Spa & 46 & 5,9 \\
\hline 7 & Konsultan pariwisata & 1 & 0,1 \\
\hline 8 & Meeting, incentive, conference, and exhibition (mice) & 9 & 1,1 \\
\hline 9 & Badan usaha pariwisata milik desa (bupmd) & 3 & 0,4 \\
\hline & Total & 789 & 100 \\
\hline
\end{tabular}

Sumber: data primer 2014

Dari sembilan jenis usaha di industri pariwisata diketahui bahwa distribusi responden keberbagai jenis usaha wisata sebagai berikut: kuliner sebesar 37,4\%, souvenir $27,4 \%$, dan akomodasi $26,6 \%$. Hal ini menunjukkan bahwa ketiga jenis usaha ini merupakan usaha utama yang paling dominan dibandingkan dengan rantai distribusi jenis-jenis usaha pariwisata perifer atau usaha pinggiran, seperti jenis usaha jasa spa 5,9\%, penyelenggaraan rapat dan pertunjukkan $1,1 \%$, bisnis perjalanan wisata $0,6 \%$, pesona landscap alam $0,5 \%$, badan usaha pariwisata milik desa $0,4 \%$, dan konsultan pariwisata $0,1 \%$. Variasi dari jenis usaha utama maupun perifer tersebut berkontribusi menentukanterwujudnya struktur pekerjaan di industri pariwisata secara riil.

Struktur pekerjaan di industri pariwisata dijelaskan berdasarkan sifat struktur organisasi dan struktur kelas pekerja. Sifat struktur organisasi industri pariwisata terdiri dari dua, yaitu tertutup dan terbuka. Sifat struktur organisasi ini terbukti berefek pada struktur kelas (Observasi, 2013). Efek tersebut ditunjukkan dengan hubungan korelasi antara terbuka tertutupnya struktur organisasi dengan struktur kelas. Semakin terbuka struktur organisasi yang diciptakan oleh jenis-jenis usaha dalam industri ini, semakin mudah peluang pekerja naik kelas. Struktur organisasi yang dimaksud adalah Struktur organisasi yang terbuka merupakan gambaran dari struktur kerja dari sebuah proses produksi komoditi yang memberikan pemerataan kesempatan kepada setiap pekerja untuk melakukan perpindahan jabatan atau bidang kerja yang membutuhkan tenaga-tenaga spesialisasi dibidangnya. Oleh karena itu, jabatandidasarkan pada kapasitas keahlian dan keprofesionalan yang dimiliki oleh pekerja.Terbentuknya jabatan dalam struktur ini juga banyak dipengaruhi oleh penggunaan teknologi dalam setiap proses produksi.Pemilik modal menyadari pentingnya kompetensi di jabatan tersebut, sehingga memposisikan dirinya di luar atau mempercayakan pengelolaan perusahaan kepada manajemen dan staff yang ahli di bidangnya. 
Sebaliknya, semakin tertutup struktur organisasi yang tercipta, semakin stagnan atau cenderung mudah pekerja tertinggal kelas. Tertinggal kelas diartikan sebagai pekerja yang menjadi skrup-skrup industri dan lapuk di pekerjaannya (Adimiharja, 2000).

Hal ini karena dalam struktur organisasi yang terbuka, peluang perpindahan pekerja antarjabatan atau antarusaha juga semakin terbuka, sedangkan dalam struktur yang tertutup peluang tersebut telah terbatasi oleh dominasi dan kekuasaan dari pemilik modal yang telah membeli tenaga kerja. Akibatnya, para pekerja yang berada dalam struktur organisasi terbuka lebih mampu naik kelas secara optimal, sedangkan dalam struktur yang tertutup kadar optimalisasi itu semakin menurun menuju pada kelas terendah dengan standar kebutuhan yang minimal.

Wujud dualisme struktur organisasi seperti itu tidak terlepas dari faktor besar kecilnya modal yang diakumulasikan.Hasil pengamatan seksama dilokasi penelitian (2013) memperlihatkan bahwa semakin besar investasi modal yang diakumulasikan, semakin luas jaringan pengelolaan,dan semakin kompleks pengaturan pembagian kerjanya membawa konsekuensi semakin terbuka struktur organisasi yang diciptakan. Struktur organisasi dalam industri pariwisata ini terus berkembang dinamis kearah yang terbuka karena perubahan teknologi, jabatan yang terus menerus berkembang, percepatan akumulasi, dan sirkulasi modal tersebut. Industri pariwisata diserap Indonesia atas dukungan dana dari Bank Dunia (pada 1968), IGGI (sejak 1966), dan IMF (1970) (Picard, 2006). Idenya digagas sejak Repelita I (1969-1974), ditetapkan sejak 1974, dan secara gradual mulai tumbuh mengesankan pada paruh pertama era 1980-an, (Picard, 2006).Dalam perkembangannya, industri ini mampu tumbuh hingga mengalami keselarasan pada paruh ke dua era 1990-an, dan sedikit penurunan pada akhir abad ke21 (era 2000-an). Beberapa sebab penurunan ini, di antaranya, krisis keamanan di Indonesia karena maraknya teroris dan teror bom sepanjang 2000-2005; wabah flu burung H5N1 dipertengahan 2002; bencana alam tsunami, gunung meletus, banjir, dan tanah longsor.

Berbagai jenis usaha ekonomi skala kecil, menengah sampai besar, semuanya tumbuh kearah itu dengan tingkat kompleksitas dan spesialisasi yang beragam. Semakin besar jenis usahanya, semakin luas jaringannya dan semakin terbuka struktur organisasi yang dibentuk, maka semakin kompleks jenis spesialisasi tenaga yang dibutuhkan untuk mengisi struktur jabatan. Semakin kecil jenis usahanya, semakin sedikit spesialisasi tenaga kerja yang dibutuhkan. Spesialisasi ini bukan berarti pekerja terisolasi di bagiannya atau teralineasi dari bagian yang lain, tetapi semua menjadi bagian yang terintegrasi dalam satu visi perusahaan dan diberikan kesempatan yang sama untuk berkarir atau berprestasi. Sehubungan dengan hal itu, penilaian loyalitas pekerja bukan pada atasan atau pimpinan, tetapi kesuksesan prestasi yang diraihnya dalam mencapai visi perusahaan. Pergerakan karir pekerja dalam struktur organisasi dari satu jabatan ke jabatan yang lain, dari satu jenis usaha ke jenis usaha yang lain, dari industri satu ke industri yang lain dari negara satu ke negara lain lintas batas atau dikenal dengan istilah proceean career merupakan tujuan pekerja mencari sederetan pengalaman dalam menguasai spesifikasi keterampilan dan keahlian yang dibutuhkan untuk membangun keprofesionalan dirinya. Artinya, pengembangan karir ditentukan oleh kebutuhan pekerja sendiri, bukan sepenuhnya tergantung perusahaan (Obersevasi, 2013).

Akan tetapi, ada juga usaha yang masih menunjukkan ciri-ciri struktur tertutup dan terkonsentrasi, tetapi keberadaanya lebih merupakan realitas-realitas pekerjaan yang bergerak di usaha perifer atau usaha semi otonom. Jenis usaha kuliner, akomodasi, dan souvenir terbukti lebih relevan dengan landscap alam yang berwajah pantai dan sedikit perbukitan. Oleh karena itu, ketiga jenis usaha ini mendominasi di bandingkan dengan jenis usaha yang lain.Jenis usaha pariwisata yang lain dapat dikatakan 
sebagai jenis-jenis usaha perifer (pinggiran). Jenis-jenis usaha ini bersifat mendukung, bukan sebagai pesaing di dalam sirkulasi maupun akumulasi modal.Jenisusaha-usaha perifer memiliki korelasi fungsi dan manfaat yang penting terhadap jalannya kegiatan kepariwisataan secara keseluruhan karena usaha-usaha tersebut memiliki simbiotik timbal balik yang saling mendukung, baik terhadap keberadaan ketiga usaha utama, maupun usaha perifernya (Observasi dan pemetaan, 2013). Satu hal yang perlu dicatat dari semua jenis usaha ini mengarah keserempakan kerja dengan struktur organisasi yang terbuka (Observasi, 2013).

Antara usaha utama dengan perifer ini terjalin simbiotik yang berefekterhadap terciptanya wujud-wujud struktur kelas pekerja dalam industri pariwisata yang bisa dilihat secara mikroskopik (spesifik) maupun makroskopik (general). Tidak dapat dipungkiri bahwa wujud mikroskopik maupun makroskopik, persoalan jabatan dan pangkat, kepemilikan dan nonkepemilikan modal, masih merupakan faktor-faktor yang memiliki efek determinan terhadap terwujudnya struktur kelas pekerja. Walaupun begitu, faktor-faktor tersebut bukanlah faktor determinan tunggal. Hasil pengamatan seksama (2013) dalam penelitian ini, memperlihatkan bahwa masih terdapat faktor-faktor penyerta lain yang cukup berefek terhadap perwujudan struktur kelas pekerja. Beberapa faktor penyerta tersebut, di antaranya, kemampuan dominasi dan kontrol atas pekerja; kemudian faktor keahlian dan keprofesionalan pekerja;kemampuan berwiraswasta yang kesemuanya tercermin dalam setiap proses produksi komoditi di sembilan jenis usaha di industri pariwisata.Hasil wawancara dengan informan penting dalam penelitian ini dapat memberi gambaran tentang hal itu.

"...sekarang ini banyak jabatan-jabatan baru yang dibutuhkan oleh hotel-hotel atau perusahaan-perusahaan pariwisata. Banyak tenaga professional yang silih berganti mengisi jabatan-jabatan itu.Mungkin saja para pekerja itu memburu gaji yang tinggi, ketenangan, kenyamanan, atau karir.Saya juga pernah dengar di tempat saya kerja ini, karena pemilik modal bukan ahli di bidangnya dan terlalu ikut campur dalam urusan kerja, sehingga banyak pekerja tidak betah dan pindah tempat kerja. Dalam dunia kerja sekarang ini semuanya serba mungkin Pak. Apalagi seperti di KedongananJimbaran ini, banyak juga lahir bos-bos baru dalam usaha hotel, kafe, dan restoran setelah mereka mendapatkan pengalaman di berbagai pekerjaan di beberapa jenis usaha industri pariwisata sebelumnya.Ya...jadinya, banyak pekerja yang keluar masuk silih berganti dengan berbagai alasannya," (Informan, Farida, pekerja di hotel Keraton Jimbaran Bali, Juli 2013).

“...iya Pak...memang banyak pekerja yang berpindah-pindah sekarang ini. Dunia karir di pariwisata telah banyak bergeser.Struktur pekerjaan banyak yang berubah.Sudah tuntutan jamannya Pak. Hotel, restoran atau kafe di Kedonganan-Jimbaran ini harus merekrut tenaga-tenaga professional baru, jika tidak ingin usahanya kalah bersaing. Oleh karena itu, perpindahan pekerja dari satu hotel ke hotel lain sudah biasa disini. Ya..., menurut saya hal itu sah-sah saja.Bahkan, sekarang ini jika hotel memecat pekerja, hal itu bukan menjadi hal yang memusingkan bagi pekerja. Dia bisa pindah ke hotel lain. Ada mantan pekerja di sini, yang dulunya dipecat, sekarang justru lebih baik karirnya.Mereka pindah menjadi pekerja di kapal pesiar, kemudian berpindah ke beberapa negara dan sekarang jabatannya di hotel intercontinental Jimbaran menjadi Food $\mathcal{E}$ Beverage Director.Namun,ada juga yang pindah bukan karena dipecat, tetapi keahlian dan keprofesionalan yang dimiliki. Menurut banyak cerita di hotel saya ini, mereka itu ada yang keluar masuk dari pekerjaan ke Australia, Cina, Saudi Arabia, Dubai, Inggris, Francis, Swiss, atau Amerika, karena profesionalismenya tersebut. Sekarang ini serba terbuka Pak karena ya ...itu tadi, struktur pekerjaan dalam usaha di industri pariwisata sekarang ini sudah kompleks dan banyak membutuhkan tenaga-tenaga kerja professional seperti itu,"(Informan, Wayan Arcana, Human Resources Hotel Four Season, Juli 2013).

Aturan di industri pariwisata, bila pekerja keluar dari perusahaan, memberitahukan ke personalia secara tertulis minimal 1 bulan sebelumnya agar industri mendapatkan 
kesempatan mencari penggantinya, ada proses over handling pekerjaan, dan proses pembuatan sartifikat pengalaman kerja bagi pekerja (KKB Hotel Four season Jimbaran, 2013).Artinya, industri pariwisata pun merasa kesulitan bila harus mengeluarkan pekerja, karena memerlukan waktu dan investasi modal besar untuk pekerja baru berorientasi mengenal budaya kerja, sejarah perusahaan, tugas pokok dan fungsi serta penyesuaian dengan tim kerjanya. Berbagai pelatihan pun harus dilakukannya dan itu tidak mudah, sementara operasional harus jalan terus dengan tuntutan pelayanan prima.

Pengalaman informan tersebut menggambarkan bila struktur kelas pekerja dalam industri pariwisata sudah sangat kompleks dan beragam.Keberagamannya tersebut membuka peluang para pekerja professional terus berpindah-pindah kerja, bahkan perpindahan kerja lintas batas. Kenyataan ini memperlihatkan bahwa dalam industri pariwisata telah terbentuk proclean career, yaitu karir yang mengalami perubahan karena aspek kebutuhan keprofesionalan pekerja, seiring dengan perubahan fungsi-fungsi jabatan karena kebutuhan dan kemajuan teknologi dalam lingkungan kerja (Noe, dkk., 2000).

Inilah tantangan terbesar pekerja industri pariwisata sekarang ini. Angkatan kerja di masa depan akan lebih beragam dan mencakup lebih banyak orang kulit berwarna, wanita, dan imigran baru dengan kebutuhan khusus, (Usmara, 2009). Kebutuhan khusus ini, misalnya beberapa bisnis perjalanan wisata atau hotel membutuhkan tenaga para expatriat bukan karena diharapkan mereka akan mentransfer ilmu dan keahliannya ke pekerja pribumi, justru banyak pekerja pribumi mempunyai kemampuan jauh lebih baik, bahkan mereka banyak belajar ke pekerja pribumi dengan magang 3-6 bulan. Ekspatriat dipekerjakan karena industri ingin menangkap segmen pasar dari negaranya. Misalnya, Expatriat asal Jepang berfungsi untuk membidik pasar Jepang karena mereka lebih percaya, lebih mudah berkomunikasi, lebih memahami budayanya, dan tahu seluk beluk kapan dan bagaimana strategi yang jitu untuk menangkap segmen ini. Begitu juga expatriat dari negara-negara yang lain, di antaranya dari Itali, Greece, dan Taiwan (observasi, Juli 2013).

Keluar masuknya pekerja atau turn over yang tinggi, ada kecenderungan untuk pengembangan karir, penghargaan, jabatan yang lebih tinggi dan lebih baik. Menurut data Dinaskertran Kabupaten Badung (2012) dan Laporan Intelligence Unit (2012) tercatat bahwa tingkat keluar masuknya pekerja di usaha industri pariwisata di beberapa Negara Asia per tahun cukup tinggi, yiatu Singapura sebesar 20\%, Thailand $14 \%$, dan Cina 12\%. Wilayah Kedonganan-Jimbaran sendiri yang termasuk dalam wilayah Bali, tingkat turn over sebesar $15 \%$ per tahunnya. Hasil analisis menunjukkan bahwa usaha di industri pariwisata saling berkompetisi untuk mendapatkan pekerja terbaiknya karena harus berkompetisi dengan usaha yang lain. Di kala usaha di industri pariwisata tersebut tidak mampu mengakomodasi kebutuhankebutuhan pekerja tersebut, maka akan ditinggalkannya. Tren ini juga diikuti oleh semakin banyaknya muncul manajer-manajer dan pengusaha-pengusaha baru dari kalangan muda-mudi di usaha industri pariwisata ini (Observasi dan pemetaan, 2013).

Di sisi lain, fenomena ini juga dipacu oleh kebutuhan keprofesionalan dari industri pariwisata maupun pekerja itu sendiri. Kemajuan teknologi dan perilaku wisatawan membuat industri harus mengembangkan fungsi-fungsi jabatan yang inovatif bersama tenaga-tenaga baru yang professional. Oleh karena itu, keluar masuknya pekerja ini sudah menjadi hal yang lazim. Seperti dikatakan oleh para informan di atas, keluar masuknya pekerja sudah tidak terbatas pada area kerja di Bali dan sekitarnya, tetapi sudah lintas batas antarnegara. Kenyataan ini menggambarkan bila struktur kelas pekerja mikroskopik dan makroskopik dalam industri pariwisata sekarang ini sudah semakin kompleks, terbuka, dan tidak bisa dideterminasi secara tunggal ke dalam kelas yang hanya menampung dua kelompok 
besar, yaitu kelas pemilik modal (kapitalis), kapital adalah uang yang diinvestasikan untuk menghasilkan lebih banyak uang dari pada untuk konsumtif. Orang yang memiliki kapital disebut kapitalis. Nama khusus para kapitalis dalam dunianya disebut borjuis. Paham yang dianutnya disebut kapitalisme. Kapitalisme adalah sistem ekonomi dimana sejumlah pemilik modal memproduksi komoditas demi keuntungan.dan proletariat (pekerja).Proletariat adalah pekerja yang menjual kerja mereka dengan imbalan

Berdasarkan pola perpindahan pekerja ini, mengisyaratkan bahwa struktur kelas pekerja yang terwujud sudah tidak bisa diklasifikasi ke dalam dua kelompok besar, yaitu pemilik kapital dengan pekerja, tetapi telah ditemukan variasi-variasi ditengahnya diantara keduanya, yaitu kelas profesional. Di daerah Kedonganan dan Jimbaran terdapat 3 wujud stuktur kelas pekerja, yaitu pemilik modal, profesional, dan proletariat dengan pola hubungan yang setara. Di sini tidak ada ketergantungan tunggal, yang ada adalah pilihan berdasarkan kemampuan potensinya masing-masing. Mereka yang tidak mengikuti pola kesetaraan, justru ditinggalkan oleh customer internal maupun eksternalnya. Customer atau pelanggan diartikan sebagai orang yang membutuhkan bantuan. Di industri pariwisata semua harus siap memberikan bantuan baik terhadap internal pelanggan maupun eksternalnya, misalnya saling membantu internal pelangan sesama atau antar kelas pekerja dengan pekerja, pekerja dengan manager, atau pekerja dengan pemilik modal dan saling membantu eksternal pelanggan pekerja dengan supplier, manager dengan temunya, dan lain-lainnya (Observasi dan pemetaan, 2013).

Variasiini, selain disebabkan oleh keterbukaan industri terhadap keluar masuknya pekerja, juga konsekuensi dari kelenturannya terhadap berbagai investasi, akumulasi modal, dan perubahan teknologi. Gambaran struktur pekerjaan di industri pariwisata Kedonganan-Jimbaran pada tabel 2 berikut dapat memperkuat pandanganpandangan empirik seperti itu.

Tabel2

Struktur Pekerjaan di Industri Pariwisata Kedonganan-Jimbaran

\begin{tabular}{|c|c|c|c|c|c|}
\hline \multicolumn{6}{|c|}{ Struktur Pekerjaan di Industri Pariwisata } \\
\hline $\begin{array}{l}\text { Struktur } \\
\text { Organisasi }\end{array}$ & \multicolumn{5}{|c|}{ Struktur Kelas Pekerja } \\
\hline \multirow{4}{*}{ Terbuka } & DTW: Pimpinan, Kabag., dan Pegawai & \multicolumn{2}{|c|}{ Owner/ shareholder/ boss } & \multirow{6}{*}{$\begin{array}{l}\text { Pemodal } \\
\text { Profesional }\end{array}$} & 1,5 \\
\hline & UPW: Manajer (pemilik), Pekerja & $\begin{array}{l}\text { Direktur/ } \\
\text { manajer/ } \\
\text { pimpinan }\end{array}$ & Pengelola & & 4,6 \\
\hline & $\begin{array}{l}\text { Akomodasi: Pemilik, Komisaris, } \\
\text { Direktur, Manejer, Penyelia, Pekerja }\end{array}$ & $\begin{array}{l}\text { Supervisor/ } \\
\text { mandor }\end{array}$ & Penyelia & & 14,6 \\
\hline & $\begin{array}{l}\text { Kuliner: Bos (pemilik), Manajer, } \\
\text { Penyelia, Pekerja }\end{array}$ & & & & \\
\hline \multirow[t]{5}{*}{ Tertutup } & $\begin{array}{l}\text { Souvenir:Bos (pemilik), Manajer, } \\
\text { Penyelia, Pekerja }\end{array}$ & \multirow{2}{*}{\multicolumn{2}{|c|}{$\begin{array}{l}\text { Pengelola, Penyelia, } \\
\text { dan atau Proletariat } \\
\text { merangkap pemodal }\end{array}$}} & & 35,4 \\
\hline & Spa: Bos (pemilik), Pekerja & & & & \\
\hline & $\begin{array}{l}\text { Konsultan:Manajer (pemilik), } \\
\text { Penyelia, Pekerja }\end{array}$ & \multirow{3}{*}{\multicolumn{2}{|c|}{$\begin{array}{l}\text { Buruh/Staf/ pekerja/ } \\
\text { honorer/ karyawan/ } \\
\text { pegawai crew/clerk/ } \\
\text { outsourching }\end{array}$}} & \multirow[t]{3}{*}{ Proletariat } & 44,0 \\
\hline & MICE:Manajer (pemilik), Pekerja & & & & \\
\hline & $\begin{array}{l}\text { BUPMD: Pimpinan, Kabag., dan } \\
\text { Pegawai }\end{array}$ & & & & \\
\hline \multicolumn{5}{|l|}{$\begin{array}{l}\text { Total } \\
(\mathrm{N}=789)\end{array}$} & 100,0 \\
\hline
\end{tabular}

Sumber: Data primer, 2013

Keterangan: daerah tujuan wisata (dtw); bisnis perjalanan wisata (bpw); meeting incentive conference exhibition (mice); badan usaha pariwisata milik desa (bupmd). 
Seperti terlihat dalam tabel 2, struktur kelas pekerja ini, apabila diklasifikasi secara makroskopik, dapat ditemukan 3kelas besar, yaitu (1) pemilik modal, (2) profesional; (3) proletariat. Pertama, pemilikmodal merupakan pekerja atas yang menginvestasikan kapitalnya untuk tujuan memperoleh nilai lebih atau keuntungan dalam setiap proses produksi komoditi yang diakumulasikan. Kelompok ini berjumlah sedikit 1,5\%, tetapi menguasai asset produksi sangat besar lebih dari $70 \%$ dari keseluruhan proses produksi di industri pariwisata yang terakumulasi dilokasi penelitian. Kemampuan penguasaan aset ini, membuat kelompok ini juga memiliki kecakapan dalam hal dominasi dan kontrol atas keseluruhan aset-asetnya yang diakumulasikan.

Golongan yang kedua, yaitu profesional yangterdiri dari pengelola, penyelia dan pekerja beridentitas ganda. Profesional ini populasinya dilokasi penelitian menunjukkan jumlah yang paling besar dari pada golongan pemilik modal atau pun proletariat. Persentase populasinya menunjukkan $54,5 \%$, dengan perincian $4,6 \%$ berposisi sebagai pengelola; $14,5 \%$ penyelia; $35,4 \%$ pekerja beridentitas ganda. Kelompok ini menguasai pengelolaan aset dan mempunyai posisi tawar terhadap pemilik modal. Sesuai dengan posisi dan jabatan yang dimiliki dalam struktur kelas pekerja, baik pengelola maupun penyelia bertugas menyatukan pemilik modal dan proletariat untuk mencapai visi perusahaan. Sehubungan dengan hal itu, penilaian loyalitas mereka bukan pada pemilik modal atau pun pimpinan yang lebih tinggi, tetapi pada prestasi yang diraihnya dalam mengemban tugas dan tanggung jawab perusahaan. Spesifikasi pekerjaan, perbedaan atas kepemilikan dominasi, dan kontrol dalam struktur kelas pekerja secara terintegrasi, semua diarahkan untuk mencapai visi perusahaan. Kelompok pengelola dan penyelia ini sama-sama berposisi tergantung keberhasilan profit perusahaan, bukan pada pemilik kapital. Mereka hidup sama-sama dari upah adalah uang dan sebagainya (bisa jadi barang, misalnya beras) yang dibayarkan sebagai balasan jasa atau pembayar tenaga yang sudah dikeluarkan untuk mengerjakan sesuatu dalam waktu yang tidak tetap atau gaji adalah balas jasa yang diterima pekerja dalam bentuk uang yang dibayarkan dalam waktu tetap di waktu tertentu, misalnya pegawai atau karyawan menerima gaji bulanan seperti kelompok yang lain proletariat yang diambil dari perhitungan profit perusahaan, bukan dari uang pribadi pemilik kapital.

Golonganketiga, yaitu para pekerja tingkat bawah atau proletariat. Mereka menjual tenaga kerja yang ditukarkan dengan upah atau gaji untuk mempertahankan hidup bersama keluarganya. Ada yang berstatus pekerja tetap dan ada yang berstatus pekerja lepas, seperti magang, honorer, pekerja harian, atau outsourching. Jumlah mereka sebesar $44 \%$ dari total populasi pekerja di sembilan jenis usaha industri pariwisata dilokasi penelitian. Keberadaan mereka dalam setiap proses produksi memiliki peran penting bagi atasan dalam upaya mencapai visi perusahaan, yaitu mendatangkan nilai keuntungan dan akumulasinya. Akan tetapi, upah atau gaji mereka lebih kecil bila dibandingkan dengan golongan diatasnya, yaitu sebatas upah minimum regional (UMR). Walaupun begitu, mereka memiliki hak yang sama dengan pekerja lain, yaitu sama-sama memperoleh pelayanan fasilitas kerja layak dalam setiap proses produksi yang dijalaninya.

Gambaran keseluruhan struktur kelas pekerja yang dibentuk inimengisyaratkan bahwa industri pariwisata sudah bervariasi dan tidak bisa digolongkan kedalam dua kelompok besar, kapitalis dan proletariat, seperti peneliti terdahulu mengolongkannya (lihat, Marx, 2006; Furaker, 1982).Kelas pekerja dalam industri pariwisata sudah terfragmented kedalam kelompok-kelompok pekerja yang profesional baik ditinjau dari aspek permodalan, spesifikasi ketrampilan dan keahlian, maupun kemandirian dan kewirausahaan. Keprofesionalan ini, juga banyak melahirkan identitas-identitas ganda dari para pekerja dalam jenis-jenis usaha di 
industri pariwisata yang menjadikannya tidak mutlak disebut sebagai pekerja. Berdasarkan observasi seksama dijenis usaha ini, beberapa individu yang telah berhasil memobilisasi dirinya ke atas menjadi seorang pengusaha yang mandiri atau kapitalis yang jauh lebih tangguh, umumnya dilalui dengan semangat kerja keras dan motivasi yang tinggi.Satu hal lagi yang cukup memungkinkan mereka memobilisasi diri seperti itu karena terbukanya struktur organisasi dalam industri ini, (Observasi, 2013).Selain menjadi pekerja, mereka menjadi pengusaha mandiri mengakumulasikan modalnya, seperti restoran, kostan, cafe, souvenir, homestay, dan atau guest house. Mereka berhasil memobilisasi diri menjadi pengusaha pinggiran sampai pengusaha utama, seperti yang terlihat dalam tabel 5.2. Sebagai pengusaha pinggiran pun, mereka memiliki karakteristik yang juga sama, yaitu mengakumulasikan modal kecil di luar sumber-sumber produksi utama para pemilik kapital besar. Mereka memiliki segmen pasar tersendiri.Bisnis perifer cenderung banyak diuntungkan dari keberadaan bisnis utama, antara lain: (1) di kala seorang Executive Chef dari hotel besar melakukan demo masakan khas bumbu Bali untuk mempromosikan produk hotelnya ke seluruh dunia, secara tidak langsung akan berdampak pada mereka yang berbisnis kuliner di Bali baik warung, cafe, restoran, dll.; (2) berdasarkan citra produk ini, citra industri, citra wilayah, citra Bali pun terpromosikan karenanya, yang akan berdampak pada usaha perifer; (3) pada tahun 1997-2000 trend istilah timeshare, hotel-hotel lokal yang ada di Bali marak melakukan pembajakan terhadap tamu-tamu yang tinggal di hotel-hotel besar dengan cara bergabung bersama marketing freeland. Di sini marketing intelligent bergerak mencari print out guest in house di hotel-hotel besar. Mereka menghubunginya dengan menawarkan berbagai macam diskon, hadiah, dan janji-janji yang menarik agar tamunya mau pindah dan menginap di hotelnya saat itu atau dengan membayar uang muka untuk menginap tahun berikutnya di kala mereka merencanakan liburan lagi ke Bali; (4) tamu yang sebelumnya tinggal di hotel besar, setelah mereka mengetahui situasi Bali, berikutnya, mereka cenderung berhemat tinggal di hotel-hotel kecil. Sebaliknya, bagi tamu yang tinggal di hotel kecil setelah mengetahui situasi Bali, jarang sekali mereka yang berpindah menginap ke hotel besar; (5) pengusaha kecil, meskipun tidak promosi, banyaknya tamu di hotel besar yang berjalan-jalan di sekitarnya atau tour di tempat-tempat tujuan wisata, luberannya ini akan berdampak pada multiplier effect ke pengusaha pariwisata perifer; (6) Pengelolaan usaha perifer banyak terinspirasi dari usaha-usaha utama yang lebih profesional. Berdasarkan pengalaman bekerja di hotelhotel besar jaringan internasional, para pekerja mencoba membuat berbagai macam bisnis (observasi, 2013).

Terkait persaingan bisnis menunjukkan bahwa kehadiran hotel berbintang tidak mempengaurhi keberadaan hotel nonbintang. Misalnya, Di kala hotel besar mengambil pasar dengan harga hotel kecil, mereka akan berbenturan dengan biaya operasional. Di kala hotel besar menjual harga di bawah kontraknya dengan bisnis perjalanan atau mitra jaringan pemasarannya di seluruh dunia, maka hotel tersebut akan kehilangan kepercayaan dan di black list terancam tidak di dukungnya. Selain itu, bila menurunkan standar atau citra yang melekat justru akan menyulitkan dan menghancurkan pasarnya sendiri. Bisnis pariwisata adalah bisnis citra dengan standar tertentu yang berorientasi keuntungan yang tinggi, sehingga memerlukan pemasarannya harus intensif. Berbeda dengan daerah di luar Bali, pemasarannya cenderung dilakukan pemerintah, sedangkan pelaku bisnis menunggu dan tamu yang datang sedikit diperebutkan, terlebih saat low season. Konteks pemasaran dalam pandangan mereka hanyalah cost center, bukan profit center. Akhirnya, keunggulan bersaing hanya dengan menjual murah dari pada menghargai profesi seorang marketing untuk mempromosikan produknya. Promosi yang 
hanya mengandalkan pemerintah kurang efisien dan efektif serta terbatas jangkauan pasar dan dananya (Observasi perbandingan pemasaran Bali dan Yogyakarta, 2013). Keuntungan yang diperoleh sama-sama dari nilai surplus hasil bekerja. Di sini sebenarnya ada proses pemberdayaan melalui pengalaman kerja dari mental pekerja berproses menjadi profesional, pengusaha kecil hingga besar dan tumbuh menjadi pemodal yang terinspirasi dari berbagai jenis usaha di lingkungan industri pariwisata di sekitarnya Kiyosaki (2010). Namun demikian, ada juga sebagian kecil dari mereka belum tentu mau dipromosikan melalui berbagai pelatihan manajemen terlebih dahulu. Alasannya, mereka merasa sudah merasa nyaman dengan posisi lama dan membayangkan ribetnya di posisi baru atau karena alasan-alasan tertentu, seperti pandangan negatif kalau mendengar kata mutasi dan atau demosi. Misalnya, seorang bellboy tidak mau susah-susah, setiap hari mendapatkan tipping dari tamu, masuk dan pulang kerja bawa uang selain gaji bulanan tanpa harus terbebani tanggung jawab atau berpikir keras hingga ke bawa pulang seperti halnya para manajer. Begini saja, pekerja juga bisa kaya (Observasi, Juli 2013).

Mereka juga bergerak dan berhak menduduki posisi kelas apapun berdasarkan kemauan dan kemampuannya. Kelas proletariat naik ke kelas profesional, kelas profesional naik ke kelas pemodal, kelas pemodal yang ingin profesional melakukan rangkap status, begitu juga kelas-kelas yang lain cenderung bergerak ke status ganda. Mobilitas baik kelas proletariat dan kelas pemilik modal ke kelas profesional atau sebaliknya ini memiliki sedikit kemiripan dengan struktur kelas berdasarkan intelegensianya yang diteliti oleh penelitipeneliti sebelumnya (lihat, Ehmer, 2014; Furaker, 1982; Szelenyi dan Martin, 1988). Satu hal lain lagi yang juga peneliti jumpai yang menguatkan penelitian ini adalah pengulangan struktur kelas sebelumnya berdasarkan perspektif Marx di industri pabrikan dengan menyebut kelas baru ini sebagai kelas intelektual (Gouldner, 1980; Kitschelt, 1993). Akhirnya, gerak simultan struktur pekerjaan dengan implikasi yang dilahirkannya ini, menentukan kesejahteraan dan kebahagiaan di masing-masing kelasnya. Perlu dicatat bahwa penelitian ini baru merupakan langkah awal, maka masih banyak lagi penelitian serupa diperlukan untuk mengkaji kesejahteraan mobilitas kelas baru ini dikaitkan dengan konsep kerja layak di berbagai jenis usaha di industri pariwisata.

\section{SIMPULAN}

Dari pembahasan di atas dapat disimpulkan bahwa struktur kelas pekerja di industri pariwisata sudah bervariasi terfragmented ke dalam kelompok-kelompok kelas proletariat, kelas pemilik modal, dan kelompok kelas baru, yaitu profesional. Kecenderungan dari kelas-kelas tersebut bergerak ke status kelas ganda, misalnya selain menjadi Sous Chef di hotel Four Season Jimbaran, pekerja ini juga memiliki Cafe Blue Moon di pantai Kedonganan yang di sewanya dari salah satu banjar di daerah tersebut.Gerak struktur kelas ini menentukan kesejahteraan dan kebahagiaan di masingmasing kelasnya. Begitulah, mobilitas kelas dan munculnya kelas baru di dunia industri pariwisata.

\section{DAFTAR PUSTAKA}

Adimihardja, K., 2000, "Politik Pendidikan Tinggi dari Masa Kolonial sampai Sekarang",Dialetika Jurnal Sosial Politik, 1 (1): 1-8.

Anker, R., 2002, “People's Security Surveys: An Outline of Methodology and Concepts",International Labour Review, 141(4): 309-329.

Creswell, J.W., 2012,Research Design: Pendekatan Kualitatif, Kuantitatif dan Mixed, Yogyakarta: Pustaka Pelajar.

Ehmer, J., 2014, “Attitudes to Work, Class Structures, and Social Change: A Review of Recent Historical Studies, "International Review of Social History 59 (1): 99-117. 
Evans, G., and Colin, M., 1998, “Identifying Class Structures: A Latent Class Analysis of the Criterion-Related and Construct Validity of the Goldthorpe Class Schema",European Sociological Review, 14: 87-106.

Farmer, R.N., 1966, “Organizational Transfer and Class Structure", The Academy of Management Journal, 9 (3): 204-216.

Friedman, D.J., 1974, “Marx's Perspective on the Objective Class Structure", Polity, 6 (3): 318-344.

Furaker, B., 1982, “The Intelligentsia as a Class under Capitalism and Socialism", Acta Sociologica, 25 (4): 455-467.

Goldthorpe, J.H., 2000, “Rent, Class Conflict, and Class Structure: A Commentary on Sorenson",American Journal of Sociology, 105 (6): 1572-1582.

Gouldner, A.W., 1980, “The Future of Intellectuals and the Rise of the New Class",Political Science Quarterly, 95 (3): 499-500.

Guy, R.F., dan Allen, D.E., 1975, “The effect of Social Class on Tolerance of Defest", Social Forces, 54 (1): 160-165.

Kiyosaki, R., 2010,Rich Dad, Poor Dad, Yogyakarta: Media Pressindo.

Kitschelt, H., 1993, “Class Structure and Social Democratic Party Strategy",British Journal of Political Science, 23 (3): 299337.

Korpi, W., 1983, The Democratic Class Struggle, London: Routledge.

Magnis-Suseno, F., 1999, Pemikiran Karl Marx: Dari Sosialisme Utopis ke Perselisihan Revisionisme, Jakarta: Gramedia Pustaka.

Marx, K., 2006,Kapital: Sebuah Kritik Ekonomi Politik, Jakarta: Hasta Mitra - Ultimus \& Institute for Global Justice.
Morgan, D., 2007, Paradigms Lost and Pragmatism Regained: Methodological Implications of Combining Qualitative and Quantitative Methods, Journal of Mixed Methods Research, 1 (1), 48-76.

Noe, R.A., Hollenbeck, J.R., Gerhart, B., dan Wright, P.M., 2000,Human Resource Management, Gaining a Competitive Advantage, Third Edition, New York: McGraw-Hill Companies, Inc.

Picard, M., 2006,Bali: Pariwisata Budaya dan Budaya Pariwisata, Jakarta: KPG, Forum Jakarta-Paris: Ecole Francaise d'Extreme-Orient.

Ritchie, J.R.B. dan Goeldner C.R., 1994,Travel, Tourism, and Hospitality Research: A Handbook for Mgr.and Researchers, Canada: John Wiley \& Sons, Inc.

Rose, D. dan Karen O., 1997,Constructing Classes: Towards a New Social Classification for the UK, London: Office for National Statistics.

Szelenyi, I. dan Martin, B., 1988, “The three Waves of New Class Theories", Theory and Society, 17 (5): 645-667.

Usmara, U., 2009,Boundaryless Career for the 21st Century, Yogyakarta: Amara Books.

Wright, E.O. dan Martin, B., 1987, “The Transformation of the American Class Structure",American Journal of Sociology, 93 (1): 1-29.

Wright, E.O. dan Singelmann, J., 1982, "Proletarianization in the Changing American Class Structure", American Journal of Sociology, 88: 176-209. 1959, Class in American Society, Glencoe: Free Press. 